\title{
Inhibition of Serotonin But Not Norepinephrine Transport during Development Produces Delayed, Persistent Perturbations of Emotional Behaviors in Mice
}

\author{
Mark S. Ansorge, Emanuela Morelli, and Jay A. Gingrich \\ Sackler institute for Developmental Psychobiology, Division of Developmental Neuroscience, Department of Psychiatry, Columbia University College of \\ Physicians and Surgeons, New York, New York 10032
}

\begin{abstract}
Serotonin (5-HT) acts as a neurotransmitter, but also modulates brain maturation during early development. The demonstrated influence of genetic variants on brain function, personality traits, and susceptibility to neuropsychiatric disorders suggests a critical importance of developmental mechanisms. However, little is known about how and when developmentally perturbed 5-HT signaling affects circuitry and resulting behavior. The 5-HT transporter (5-HTT) is a key regulator of extracellular 5-HT levels and we used pharmacologic strategies to manipulate 5-HTT function during development and determine behavioral consequences. Transient exposure to the 5-HTT inhibitors fluoxetine, clomipramine, and citalopram from postnatal day 4 (P4) to P21 produced abnormal emotional behaviors in adult mice. Similar treatment with the norepinephrine transporter (NET) inhibitor, desipramine, did not adversely affect adult behavior, suggesting that 5-HT and norepinephrine (NE) do not share the same effects on brain development. Shifting our period of treatment/ testing to P90/P185 failed to mimic the effect of earlier exposure, demonstrating that 5-HT effects on adult behavior are developmentally specific. We have hypothesized that early-life perturbations of 5-HT signaling affect corticolimbic circuits that do not reach maturity until the peri-adolescent period. In support of this idea, we found that abnormal behaviors resulting from postnatal fluoxetine exposure have a post-pubescent onset and persist long after reaching adult age. A better understanding of the underlying 5-HT sensitive circuits and how they are perturbed should lead to new insights into how various genetic polymorphisms confer their risk to carriers. Furthermore, these studies should help determine whether in utero exposure to 5-HTT blocking drugs poses a risk for behavioral abnormalities in later life.
\end{abstract}

Key words: serotonin; depression; development; antidepressants; mouse; behavior

\section{Introduction}

Neurotransmitters such as serotonin (5-HT) and norepinephrine (NE) play an important role during brain development in which they act as trophic factors modulating processes such as neuronal division, differentiation, migration, growth cone elongation, axonal guidance, synaptogenesis, and dendritic pruning. Findings from genetic and pharmacologic studies indicate that bioamine signaling during early life are critically involved in the development of brain circuits that modulate adult emotional behavior.

For example, variants in genes that regulate 5 -HT or NE levels alter adult emotional behavior in humans (Reif and Lesch, 2003; D'Souza and Craig, 2006; Kim et al., 2006; Zhang et al., 2006), nonhuman primates (Barr et al., 2004; Newman et al., 2005) and mice (Gross et al., 2000; Xu et al., 2000; Popova et al., 2001; Lira et

\footnotetext{
Received Aug. 30, 2007; revised 0ct. 10, 2007; accepted Nov. 10, 2007.

This work was supported by The Sackler Institute for Developmental Psychobiology, a National Alliance for Research on Schizophrenia and Depression Young Investigator Award (M.S.A.), and the National Institute of Mental Health. We thank N. Weisstaub, M. Milekic, T. Rebello, Q. Yu, and N. Gray for their critical review of this manuscript and T. Cooper for the analytical work.

Correspondence should be addressed to Jay A. Gingrich, Sackler Institute for Developmental Psychobiology, Division of Developmental Neuroscience, Department of Psychiatry, Columbia University College of Physicians and Surgeons, New York, NY 10032. E-mail: jag46@columbia.edu.

D01:10.1523/JNEUROSCI.3973-07.2008

Copyright $\odot 2008$ Society for Neuroscience $\quad$ 0270-6474/08/280199-09\$15.00/0
}

al., 2003; Dziedzicka-Wasylewska et al., 2006; Kalueff et al., 2006; Keller et al., 2006). In the case of 5-HT transporter (5-HTT), genetically driven inhibition constitutes a risk factor for affectiverelated abnormalities in rodents, primates, and humans (Murphy et al., 2001; Ansorge et al., 2007). Paradoxically, this observation contrasts the effect of pharmacologic 5-HTT blockade during adulthood in which it ameliorates anxiety and depression-related behaviors in humans (Owens and Nemeroff, 1998; Berton and Nestler, 2006) and rodents (Cryan et al., 2002; Dulawa and Hen, 2005). The developmental component of genetic 5 - $h t t$ blockade could explain this paradox and comports with findings that earlylife exposure to various drugs that block 5-HTT function alter adult behavior in rodents (Vogel et al., 1990; Maciag et al., 2006). A direct comparison of transient pharmacologic and lifelong genetic 5-HTT blockade in mice demonstrated that early postnatal (PN) fluoxetine treatment mimics the effect of genetic 5-htt ablation on emotional behavior (Ansorge et al., 2004). These findings suggest that other drugs, which block 5-HTT function, share the adverse effects of fluoxetine on adult emotional behavior when administered during development. Alternatively, the pharmacokinetic (e.g., long half-life, active metabolites) and/or pharmacodynamic (e.g., non-5-HTT effects such as activity at the norepinephrine transporter NET, the background potassium channel TREK-1, and 5-HT2C receptors) properties of fluox- 
etine have also been postulated to exert CNS effects that could influence development (Carrasco and Sandner, 2005; Heurteaux et al., 2006). To address this question, we examined the effect of early postnatal exposure to several chemically distinct compounds that exhibit varying half-lives and affinities for the 5-HTT and the NET by determining the degree to which they recapitulate the behavioral phenotype of PN-fluoxetine-treated and thus 5-htt-deficient mice.

Previous studies also indicate that early postnatal development constitutes a critical period during which 5-HTT blockade impacts adult emotional behavior (Feng et al., 2001; Ansorge et al., 2007). Alternatively, chronic but transient 5-HTT blockade at any time during the postnatal life could leave a long-lasting trace in behavior after cessation of treatment. Here, we investigate this question in combination with an ontogenetic characterization of the behavioral phenotype.

\section{Materials and Methods}

Subjects. WT (129S6/SvEv) mice and mice heterozygous for the 5-htt mutation $\left(5-\mathrm{htt}^{+/-}\right.$, 10th generation, 129S6/SvEv) were crossed to produce 5- $h t t^{+/+}, 5-h t t^{+/-}$offspring. For the studies involving postnatal drug administrations, mixed litters were culled to five pups. On postnatal day 4 (P4), pups were tattooed and randomly assigned to vehicle $(0.9 \%$ $\mathrm{NaCl}, 5 \mathrm{ml} / \mathrm{kg}$, i.p.), fluoxetine (10 mg/kg, $5 \mathrm{ml} / \mathrm{kg}$, i.p.), desipramine (10 $\mathrm{mg} / \mathrm{kg}, 5 \mathrm{ml} / \mathrm{kg}$, i.p.), citalopram ( $10 \mathrm{mg} / \mathrm{kg}, 5 \mathrm{ml} / \mathrm{kg}$, i.p.), and clomipramine ( $20 \mathrm{mg} / \mathrm{kg}, 5 \mathrm{ml} / \mathrm{kg}$, i.p.) treatment. Mice were treated once per day from P4 to P21. For treatment, entire litters were removed from dams and placed into a bucket $(10 \mathrm{~cm}$ diameter) containing shavings from the respective home cage. The bucket was resting on scales, to allow for weighing mice after picking them up. Mice were injected in random order, and an entire litter was injected within 2 min. Immediately after injection, mice were placed back into the home cage. For nontreated control mice, entire litters in the same breeding cohort were left noninjected and non-handled except for weekly cage changing. Mice were weaned on P28 and tissue samples were harvested. Mice were genotyped using PCR of genomic DNA isolated from tissue samples. Animals were separated by sex and group housed with both WT and 5-htt ${ }^{+/-}$mice present in each cage. For the studies involving postnatal drug administrations, each cage also contained mice that had received different drug treatments. Mice were maintained on a $12 \mathrm{~h}$ light/dark cycle (8:00 A.M./ 8:00 P.M.) and provided with food and water ad libitum (except as noted). Animal testing was conducted in accordance with the Principles of Laboratory Animal Care National Institutes of Health guidelines and the institutional animal committee guidelines.

Drugs. For the studies involving postnatal drug administrations, fluoxetine (ANAWA Trading SA, Wangen, Switzerland), desipramine (ANAWA Trading SA), citalopram hydrobromide (Tocris Bioscience, Ellisville, MO), and clomipramine (Sigma, St. Louis, MO) were dissolved in $0.9 \% \mathrm{NaCl}$ to achieve the following concentrations: fluoxetine, $2 \mathrm{mg} /$ $\mathrm{ml}$; desipramine, $2 \mathrm{mg} / \mathrm{ml}$; citalopram, $2 \mathrm{mg} / \mathrm{ml}$; and clomipramine, 4 $\mathrm{mg} / \mathrm{ml}$. Solutions were prepared fresh every day. For the study involving chronic adult drug treatments, fluoxetine was dissolved in drinking water at $100 \mathrm{mg} /$ liter to achieve an $\sim 10 \mathrm{mg} \cdot \mathrm{kg}^{-1} \cdot \mathrm{d}^{-1}$ dosing. Fluoxetine was delivered in opaque bottles to protect from light. Drug and drug metabolite levels were measured in serum and whole brain $(n=4-5$ per treatment and time point). Fluoxetine and norfluoxetine levels were determined by liquid chromatography with fluorescence detection (Suckow et al., 1992). Desipramine, clomipramine, and desmethylclomipramine levels were determined by gas-liquid chromatography using a nitrogen detector (Cooper et al., 1975; Jason et al., 1981). Citalopram, desmethylcitalopram, and didesmethylcitalopram levels were determined by liquid chromatography with fluorescence detection (Meng and Gauthier, 2005).

Behavioral testing. Four main behavioral experiments were performed: the postnatal antidepressant treatment (PN-antidepressant) experiment, the nontreated control experiment, the adult chronic fluoxetine experiment, and the PN-fluoxetine-elicited behavioral ontogeny experiment.
In the $\mathrm{PN}$-antidepressant experiment, animals were exposed to a series of behavioral paradigms designed to assess a range of anxiety, depression, and stress-related behaviors. The tests were administered in the following order: open field, elevated plus maze, novelty-suppressed feeding (NSF), novelty-induced hypophagia (NIH), and shock escape. A minimum of $7 \mathrm{~d}$ was allowed between each test. Our testing group consisted of at least eight mice per treatment, genotype, and sex. After collapsing for genotype and sex, this group consisted of at least 32 mice per treatment. The exact number of mice per treatment used in the behavioral tests performed under this experiment is shown in supplemental Table S1 (available at www.jneurosci.org as supplemental material).

In the adult chronic fluoxetine treatment experiment, animals were treated from P90 to P108 with either fluoxetine or vehicle. At P185, 2.5 months after cessation of treatment, mice were tested sequentially in the open field test, in the novelty-suppressed feeding test, and the shock escape test. This experiment was designed to determine whether chronic fluoxetine treatment later in life mimics the effects of exposure occurring in the immediate postnatal period. A minimum of $7 \mathrm{~d}$ was allowed between each test. We tested 30 male $5-h t^{+/+}$mice, 15 mice per treatment (supplemental Table S1, available at www.jneurosci.org as supplemental material).

In the nontreated control experiment, animals were tested in the open field test. This group consisted of male $5-h t t^{+/+}$mice, at least 25 mice per treatment. The exact number of mice per treatment used in this experiment is shown in supplemental Table S1 (available at www.jneurosci.org as supplemental material).

In the ontogeny experiment, animals were tested in the open field test. Three independent and naive groups of mice were tested. The first group consisted of 2-month-old mice with at least eight mice per treatment, genotype, and sex. After collapsing for genotype and sex, this group consisted of at least 35 mice per treatment. The second group consisted of 3 -month-old mice with at least 10 mice per treatment, genotype, and sex. After collapsing for genotype and sex, this group consisted of at least 40 mice per treatment. The third group consisted of 16-month-old male mice with at least 10 mice per treatment and genotype. After collapsing for genotype, this group consisted of at least 20 mice per treatment. The exact number of mice per treatment used in the behavioral tests performed under the ontogeny experiment is shown in supplemental Table S1 (available at www.jneurosci.org as supplemental material).

All behavioral testing took place between 10:00 A.M. and 2:00 P.M. with the exception of novelty-suppressed feeding (4:00 P.M. to 7:00 P.M.) and shock escape (12:00 A.M. to 6:00 P.M.). To eliminate odor cues, all testing apparatus were thoroughly cleaned after each animal using the disinfectant Roccal (Pfizer, New York, NY) diluted 100-fold.

Open field test. The open field test was performed as previously described (Lira et al., 2003). Briefly, mice were tested in Plexiglas activity chambers (model ENV-520; Med Associates, Georgia, VT) $(43.2 \times$ $43.2 \times 30.5 \mathrm{~cm}$, length $\times$ width $\times$ height) equipped with infrared beams located $1.5 \mathrm{~cm}$ above the chamber floor and spaced $2.5 \mathrm{~cm}$ apart to detect horizontal activity. Vertical activity was detected using another set of infrared beams affixed $6 \mathrm{~cm}$ above the chamber floor and spaced $2.5 \mathrm{~cm}$ apart. Mice were placed into the center of the open field and activity was recorded for $60 \mathrm{~min}$. Testing took place under bright ambient light conditions (800-900 lux). The center area was defined as the central $15 \times 15$ $\mathrm{cm}$ portion. Total ambulatory time, total rear counts, total ambulatory time in the periphery, total ambulatory time in the center, and total time in the center were measured.

Elevated plus maze. The elevated plus maze was performed as previously described (Lira et al., 2003). Briefly, animals were placed into the central area facing one closed arm and allowed to explore the maze for 5 min. Behavior was recorded by a video camera positioned above the maze. Testing took place in bright ambient light conditions (800-900 lux). An observer blind to mouse genotype scored the videotapes. The following parameters were measured: entries and time spent in open and closed arms. Total arm entries and total time spent in the open arm were calculated.

Novelty-suppressed feeding. The novelty-suppressed feeding test was performed as previously described (Lira et al., 2003). Briefly, food deprived mice $(24 \mathrm{~h}$ with water available ad libitum) were placed in a 
Table 1. Published half-lives and affinities of antidepressant drugs and drug metabolites used in this study

\begin{tabular}{|c|c|c|c|c|c|}
\hline \multirow[b]{2}{*}{ Drug and drug metabolite(s) } & \multicolumn{3}{|l|}{ Half-lives } & \multicolumn{2}{|l|}{$K_{\mathrm{i}}(\mathrm{nm})$} \\
\hline & Mice & Rats & Humans & 5-HTT & NET \\
\hline Fluoxetine & $6.8 \mathrm{~h}^{d}$ & $5 h^{e}$ & $1-4 d^{a}$ & $6.8^{a}$ & $370^{a}$ \\
\hline Norfluoxetine & $12.3 \mathrm{~h}^{d}$ & $15 h^{e}$ & $7-15 d^{a}$ & $3.8^{a}$ & $580^{a}$ \\
\hline Citalopram & $90 \min ^{f}$ & $3 h^{f}$ & $1.5 d^{a}$ & $1.8^{a}$ & $6100^{a}$ \\
\hline desM-citalopram & & & $2 d^{a}$ & $14^{a}$ & $740^{a}$ \\
\hline Clomipramine & $127 \min ^{b}$ & $6 \mathrm{~h}^{\mathrm{c}}$ & $24 \mathrm{~h}^{h}$ & $1.5^{a}$ & $21^{a}$ \\
\hline desM-clomipramine & & $5.5 h^{c}$ & $96 \mathrm{~h}^{h}$ & & \\
\hline Desipramine & & $9 h^{g}$ & $22.4 h^{a}$ & $200^{a}$ & $0.83^{a}$ \\
\hline
\end{tabular}

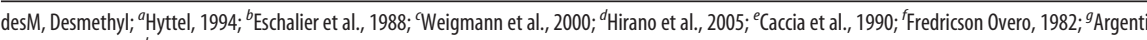
and D'Mello, 1994; ${ }^{h}$ Balant-Gorgia et al., 1991.
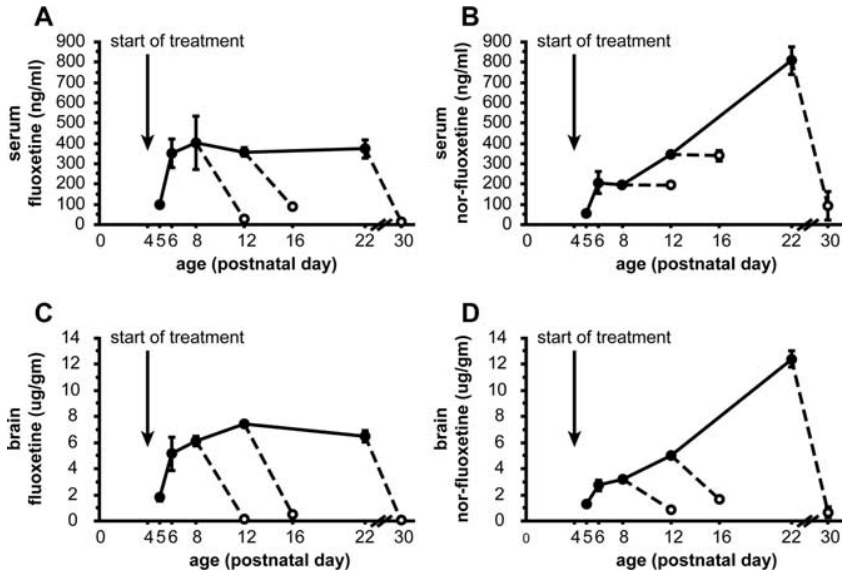

Figure 1. Fluoxetine and norfluoxetine levels in serum and brain of PN-fluoxetine treated mice. $\boldsymbol{A}$, Serum fluoxetine levels. $\boldsymbol{B}$, Serum norfluoxetine levels. $\boldsymbol{C}$, Brain fluoxetine levels. $\boldsymbol{D}$, Brain norfluoxetine levels. Solid lines and filled circles indicate that mice received $\mathrm{PN}$-fluoxetine treatment. Dashed lines and open circles indicate cessation/ending of PN-fluoxetine treatment. Mean \pm SEM values are shown ( $n=4-5$ per data point).

brightly lit (800-900 lux) open arena $(51 \times 35 \mathrm{~cm})$ containing clean wood chip bedding. A white filter paper $125 \mathrm{~mm}$ in diameter was placed in the center of the arena and one familiar food pellet weighing $\sim 4 \mathrm{~g}$ was attached to the paper. Mice were removed from their home cage, placed in a holding cage for $30 \mathrm{~min}$ before the test, and then placed in one corner of the arena. The latency to approach the pellet and begin a feeding episode was recorded (maximum time was $10 \mathrm{~min}$ ). Immediately after initiating a feeding episode, mice were removed from the arena and placed into their home cage containing a preweighed food pellet and allowed to feed ad libitum for $5 \mathrm{~min}$. Food consumption was determined by the difference in weight of the pellet.

Novelty-induced hypophagia. The novelty-induced hypophagia test was performed as previously described (Dulawa et al., 2004). Briefly, mice were trained for $3 \mathrm{~d}$ to drink diluted (25\%) sweetened condensed milk from serological pipettes with sippers attached. Training was achieved by exposing group housed mice to one filled pipette per cage (with food and drinking water in place) overnight on day 1 and for 30 min during the day on day 2 and day 3. Home-cage testing occurred on day 4: mice were removed from their home cage and placed into a holding cage. After $15 \mathrm{~min}$, one mouse was returned to the home cage with a pipette in place. The latency to drink and the volume consumed were recorded every $5 \mathrm{~min}$ for $30 \mathrm{~min}$. After $30 \mathrm{~min}$, the mouse was removed and placed into a new holding cage, the pipette was cleaned and the next mouse was tested. Home-cage testing occurred under dim lighting ( 50-100 lux). Novel cage testing occurred on day 5, when mice were placed into new clean cages of the same dimensions but without shavings, with pipettes containing the milk positioned. Novel cage testing occurred under bright lighting (800-900 lux), with white paper placed under cages. The latency to drink and the volume consumed were recorded every $5 \mathrm{~min}$ for $30 \mathrm{~min}$.

Shock escape. The shock escape test was performed as previously de- scribed (Lira et al., 2003). Briefly, mice were tested in a Plexiglas box (model ENV 010MD; Med Associates) located within a soundattenuated chamber. The box was divided into two identical chambers $(20 \times 17 \times 20 \mathrm{~cm}$, length $\times$ width $\times$ height) and separated by an automated guillotine door. The apparatus was equipped with a grid floor made of a stainless steel and connected to a shock generator, and 8 infrared beams for detecting position and activity of the animal. Mice were placed into the chamber with the guillotine door raised and were allowed to freely explore both compartments for $5 \mathrm{~min}$.

At the beginning of each trial, the door was raised and a mild scrambled foot shock $(0.2 \mathrm{~mA} ; 10 \mathrm{~s}$ duration) was delivered to the subject. The end of a trial was signaled by the closing of the guillotine door and was triggered either by a transition to the opposite chamber or after $10 \mathrm{~s}$. Transition latencies were recorded. If the subject failed to make a transition during the $10 \mathrm{~s}$ duration of the foot shock, a maximum latency of $10 \mathrm{~s}$ was recorded. A session consisted of 30 trials separated by a $30 \mathrm{~s}$ intertrial interval.

Statistical analysis. Data were analyzed using Student's $t$ test, one-way, or two-way ANOVA. The criterion for significance for all analyses was $p<0.05$. The criterion for a trend was $0.05<=p<0.1$. Post hoc comparisons were conducted using the Student-Newman-Keuls test. Datasets containing male and female mice and/or 5- htt $t^{+/+}$and 5-htt ${ }^{+/-}$ mice were analyzed for sex $\times$ treatment, sex $\times$ genotype, or genotype $\times$ treatment interactions. In line with previously published data (Lira et al., 2003; Ansorge et al., 2004), no significant effects were detected for these interactions (data not shown) and groups were collapsed for sex and genotype.

\section{Results}

Blockade of 5-HTT during development using fluoxetine, citalopram, clomipramine, and desipramine

To test the hypothesis that the adverse consequences of PNfluoxetine treatment on adult emotional behavior are shared by other drugs with 5-HTT blocking properties, we exposed mice to citalopram, clomipramine, and desipramine during P4-P21. These compounds are structurally distinct from fluoxetine, vary in their specificities and affinities to the 5-HTT, and differ in their half-lives (Table 1). The reported adult half-lives for these drugs led us to predict that our once-per-day injections would produce steady-state levels only for fluoxetine and its metabolite, norfluoxetine, but not for any of the other compounds.

To investigate the pharmacokinetics of PN-fluoxetine treatment, we analyzed serum and brain levels $1,2,4,8$, and $18 \mathrm{~d}$ after treatment initiation, $24 \mathrm{~h}$ after the last injection. Serum and brain fluoxetine levels reached steady state after $\sim 2-4 \mathrm{~d}$ of treatment (Fig. $1 A, C$ ). Serum and brain norfluoxetine levels gradually increased until P22 (Fig. 1B,D). To determine whether the gradual buildup of norfluoxetine was attributable to an inability in pups to metabolize and clear norfluoxetine, we analyzed serum and brain levels $4 \mathrm{~d}$ after cessation of 4 and $8 \mathrm{~d}$ treatments and $8 \mathrm{~d}$ after cessation of $18 \mathrm{~d}$ of treatment. Cessation of treatment led to a decline in fluoxetine levels in serum and brain at all ages. Brain norfluoxetine levels also declined at all ages. Serum norfluoxetine levels did not decline at the 8 and $12 \mathrm{~d}$ time points but declined at the $30 \mathrm{~d}$ time point (Fig. $1 A-D$ ). This finding suggests that the half-life of norfluoxetine is dynamic during development. In the brain, norfluoxetine has a half-life of $<2 \mathrm{~d}$ at all ages investigated.

To investigate the pharmacokinetic properties of $\mathrm{PN}$ clomipramine, PN-citalopram and PN-desipramine treatment, we analyzed drug and drug metabolite levels in brain and serum on P21, $4 \mathrm{~h}$ after the last injection, and on P22, $24 \mathrm{~h}$ after the last 
Table 2. Antidepressant drug and drug metabolite levels 4 and $24 \mathrm{~h}$ after $\mathrm{PN}$-antidepressant treatment

\begin{tabular}{|c|c|c|c|c|c|c|c|c|}
\hline \multirow[b]{3}{*}{ Drug and drug metabolite(s) } & \multicolumn{4}{|c|}{$4 \mathrm{~h}$ after injection } & \multicolumn{4}{|c|}{$24 \mathrm{~h}$ after injection } \\
\hline & \multicolumn{2}{|c|}{ Plasma (ng/ml) } & \multicolumn{2}{|c|}{ Brain $(\mu \mathrm{g} / \mathrm{g})$} & \multicolumn{2}{|c|}{ Plasma (ng/ml) } & \multicolumn{2}{|c|}{$\operatorname{Brain}(\mu \mathrm{g} / \mathrm{g})$} \\
\hline & Mean & SD & Mean & SD & Mean & SD & Mean & SD \\
\hline Desipramine & ND & ND & 0.28 & 0.18 & ND & ND & ND & ND \\
\hline Clomipramine & 60 & 1.41 & 0.38 & 0.14 & ND & ND & ND & ND \\
\hline desM-clomipramine & ND & ND & 0.22 & 0.06 & ND & ND & ND & ND \\
\hline Citalopram & 23.5 & 1.73 & 0.8 & 0.21 & ND & ND & 0.02 & 0.03 \\
\hline desM-citalopram & 38.6 & 4.04 & 0.34 & 0.03 & ND & ND & ND & ND \\
\hline didesM-citalopram & 37.4 & 4.83 & 0.1 & 0.01 & ND & ND & ND & ND \\
\hline
\end{tabular}

desM, Desmethyl; didesM, didesmethyl.

injection. The results are shown in Table 2. Of note, $24 \mathrm{~h}$ after the last injection only very low citalopram levels could be detected in the brain; hence, we did not investigate the half-life of these drug and drug metabolite levels over the P4-P21 period in more detail. Our results demonstrate that injection protocols with clomipramine, citalopram and desipramine do not produce steady state levels in the serum or the brain and thus only lead to transient periods of 5-HTT inhibition each day after injection.

\section{The effect of $\mathrm{PN}$-antidepressant treatment on exploratory activity in a novel environments}

At 3-3.5 months of age, $\mathrm{PN}$-antidepressant and $\mathrm{PN}$-vehicletreated mice were tested in two novel environments: the open field and in the elevated plus maze. In both environments, we observed a treatment effect on exploratory activity. Specifically, we detected a treatment effect for total ambulatory time $\left(F_{(4,224)}\right.$ $=3.280, p=0.0123$ ) (Fig. $2 A)$ and total vertical activity $\left(F_{(4,225)}\right.$ $=2.873, p=0.0238$ ) (Fig. $2 B$ ) in the open field. Post hoc analysis revealed that $\mathrm{PN}$-fluoxetine and $\mathrm{PN}$-clomipramine treatment both significantly reduced total ambulatory time $(p=0.0042$ and $p=0.0023$, respectively) (Fig. $2 A$ ) and vertical activity ( $p=$ 0.0061 and $p=0.0439$, respectively) (Fig. $2 B$ ), when compared with $\mathrm{PN}$-vehicle-treated control mice. $\mathrm{PN}$-citalopram treatment only reduced total ambulatory time ( $p=0.0404)$ (Fig. $2 A$ ), whereas $\mathrm{PN}$-desipramine-treated mice were unaffected in all measures. Analysis of ambulatory activity in the periphery of the open field also revealed a main effect of treatment $\left(F_{(4,224)}=\right.$ 3.242, $p=0.0130$ ) (supplemental Fig. S1 A, available at www. jneurosci.org as supplemental material). Post hoc analysis revealed that $\mathrm{PN}$-fluoxetine, $\mathrm{PN}$-clomipramine, and $\mathrm{PN}$ citalopram treatment significantly reduced total ambulatory time in the periphery $(p=0.0048, p=0.0030$, and $p=0.0236$, respectively) (supplemental Fig. S1A, available at www. jneurosci.org as supplemental material). Analysis of ambulatory activity in the center of the open field did not revealed a main effect of treatment $\left(F_{(4,224)}=2.176, p=0.0725\right)$ (supplemental Fig. $\mathrm{S} 1 B$, available at www.jneurosci.org as supplemental material). In the elevated plus maze, an overall treatment effect was detected for total arm entries $\left(F_{(4,207)}=4.554, p=0.0015\right)$ (Fig. $2 C$ ), and post hoc analysis revealed that it was the PN-fluoxetine, $\mathrm{PN}$-clomipramine, and PN-citalopram treatments that significantly reduced total exploratory activity when compared with PN-vehicle-treated mice $(p=0.0001, p=0.0288$, and $p=$ 0.0353 , respectively) (Fig. $2 C$ ). As in the open field environment, $\mathrm{PN}$-desipramine treated mice did not display behavioral differences when compared with PN-vehicle-treated mice (Fig. 2C). In both tests, no effect was seen on the anxiolytic-sensitive measures center time $\left(F_{(4,221)}=1.007, p=0.4045\right)$ (supplemental Fig. S1C, available at www.jneurosci.org as supplemental material) and open arm time $\left(F_{(4,207)}=0.807, p=0.5220\right)$ (supplemental Fig.
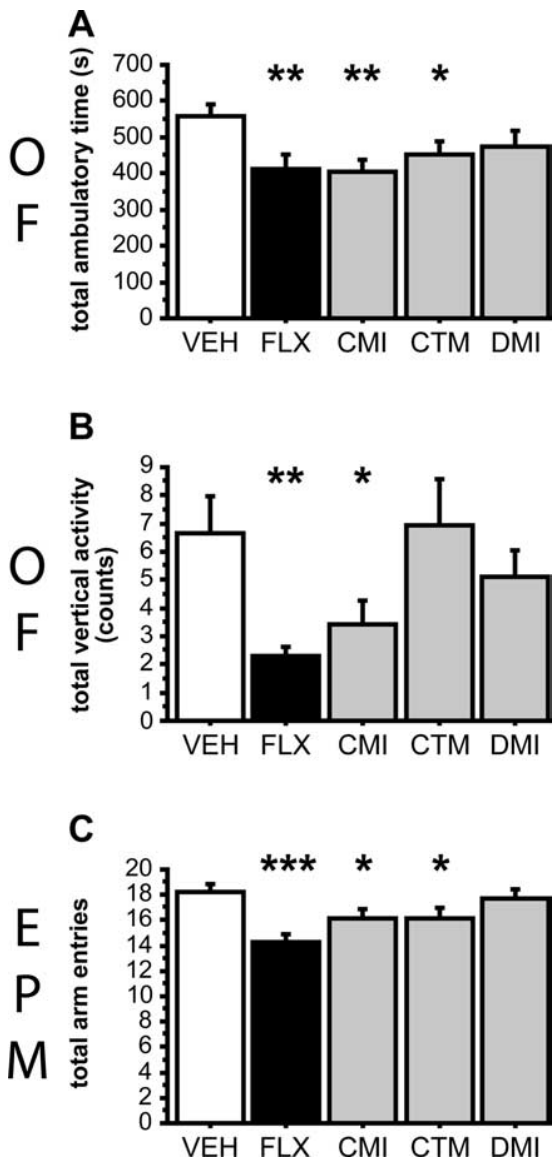

Figure 2. Exploratory behavior in the novel open field and the elevated plus maze of PNantidepressant- and PN-vehicle-treated mice. $\boldsymbol{A}$, Total ambulatory time in the novel open field (OF). $\boldsymbol{B}$, Total vertical activity in the novel open field. $\boldsymbol{C}$, Total arm entries in the elevated plus maze (EPM). VEH, PN-vehicle; FLX, PN-fluoxetine; CMI, PN-clomipramine; CTM, PN-citalopram; DMI, PN-desipramine. Mean \pm SEM values are shown ( $n=40-65$ per group). ${ }^{*} p<0.05$; ${ }^{* *} p<0.01$; ${ }^{* * *} p<0.001$ compared with PN-vehicle.

S1 $D$, available at www.jneurosci.org as supplemental material). We performed a control experiment to establish whether our postnatal injection procedure by itself alters adult emotional behavior. This possibility is based on the extensive literature demonstrating effects of early-life environmental manipulations, such as handling and maternal separation, on adult emotional behavior (Meaney et al., 1988; Tang et al., 2006; Lippmann et al., 2007). Using an independent group of naive mice, we compared the behavior of PN-fluoxetine- and PN-vehicle-treated mice with nontreated mice in the open field test at 3 months of age. We detected a main effect of treatment for total ambulatory time $\left(F_{(2,102)}=4.961, p=0.0088\right)$ (supplemental Fig. S2 A, available at 

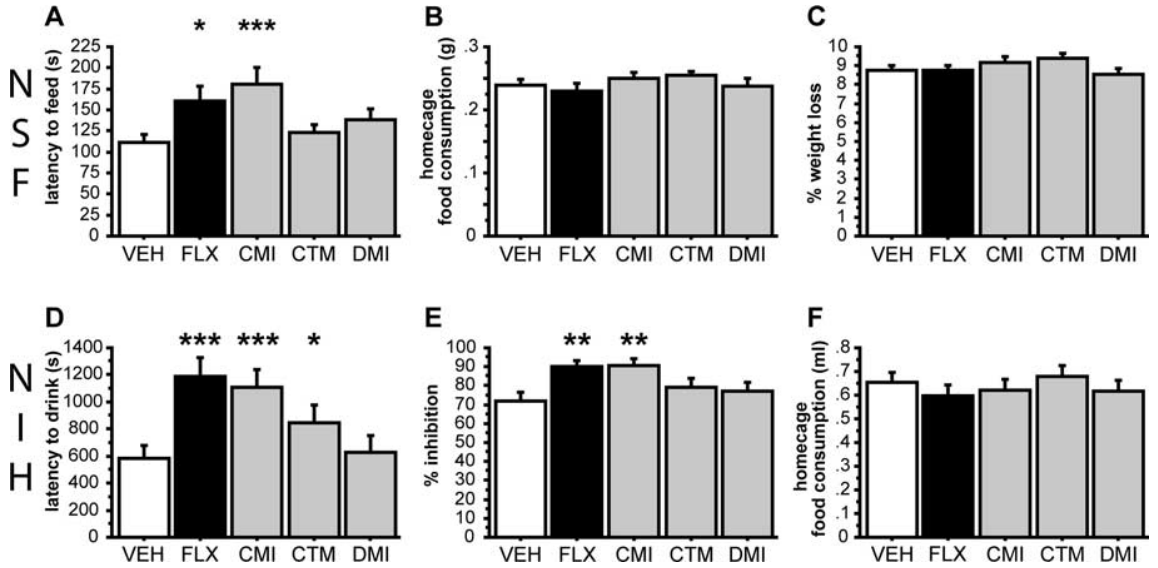

Figure 3. Behavioral measures of PN-antidepressant and PN-vehicle treated mice in hyponeophagia tests. $A-C$, NSF. $A$, Latency to feed; $\boldsymbol{B}$, home-cage food consumption; $\boldsymbol{C}$, weight loss. $\boldsymbol{D}-\boldsymbol{F}$, NIH. $\boldsymbol{D}$, Latency to drink; $\boldsymbol{E}$, inhibition; $\boldsymbol{F}$, home-cage food consumption. VEH, PN-vehicle; FLX, PN-fluoxetine; CMI, PN-clomipramine; CTM, PN-citalopram; DMI, PN-desipramine. Mean \pm SEM values are shown ( $n=32-58$ per group). ${ }^{*} p<0.05 ;{ }^{* *} p<0.01 ;{ }^{* * *} p<0.001$ compared with PN-vehicle.

www.jneurosci.org as supplemental material), total vertical activity $\left(F_{(2,102)}=5.904, p=0.0037\right)$ (supplemental Fig. S2 B, available at www.jneurosci.org as supplemental material), and total ambulatory activity in the periphery $\left(F_{(2,102)}=5.224, p=\right.$ 0.0069) (supplemental Fig. S2C, available at www.jneurosci.org as supplemental material), but not total ambulatory activity in the center $\left(F_{(2,102)}=0.350, p=0.7052\right)$ (supplemental Fig. S2 D, available at www.jneurosci.org as supplemental material). Post hoc analysis revealed that PN-fluoxetine treatment significantly reduced total ambulatory time, total vertical activity and total ambulatory time in the periphery when compared with both PNvehicle-treated mice ( $p=0.0171, p=0.0101$, and $p=0.0125$, respectively) as well as nontreated control mice ( $p=0.0028, p=$ 0.0011 , and $p=0.0024$, respectively). No significant difference was detected between $\mathrm{PN}$-vehicle-treated mice and nontreated control mice for any of the measures.

The effect of PN-antidepressant treatment in tests sensitive to chronic antidepressant treatment

The NSF test and the NIH test exhibit predictive validity for anxiolytic and chronic antidepressant drug treatments, mimicking the delayed onset of therapeutic efficacy seen in the clinical setting.

In the NSF, food-deprived mice are presented with a familiar food pellet in a novel, brightly lit environment and the latency to approach the food and begin a feeding bout is recorded. An overall treatment effect was detected for the latency to feed $\left(F_{(4,180)}=\right.$ 3.933, $p=0.0044$ ) (Fig. 3A). Post hoc analysis revealed that PNfluoxetine and $\mathrm{PN}$-clomipramine treatments both significantly increased the latency to feed compared with PN-vehicle treatment ( $p=0.0184$ and $p=0.0005$, respectively) (Fig. $3 A)$. PNdesipramine- and $\mathrm{PN}$-citalopram-treated mice were unaffected. No differences between treatment groups were seen for the control measures percentage weight loss achieved by the food deprivation $\left(F_{(4,175)}=1.052, p=0.3817\right.$. $)$ or home-cage food consumption after the test $\left(F_{(4,175)}=1.488, p=0.2080\right)($ Fig. $3 B, C)$.

Unlike the NSF, the NIH test does not depend on food deprivation or locomotor activity. Rather, it assesses the drive to drink a sweetened milk solution in non-food-deprived mice. To control for possible differences in the motivation to consume the sweetened milk, home-cage consumption was assessed. No treatment effect was detected for latency to feed (data not shown) and total milk consumption $\left(F_{(4,209)}=0.788\right.$, $p=0.5343$ ) (Fig. $3 F)$. On the testing day, milk consumption was monitored in a novel environment. A treatment effect was detected for the latency to feed $\left(F_{(4,209)}=\right.$ 5384, $p=0.0004)$ and percentage inhibition of milk consumption $\left(F_{(4,209)}=3.484\right.$, $p=0.0089$ ) (Fig. $3 D, E)$. Post hoc analysis revealed that $\mathrm{PN}$-fluoxetine, $\mathrm{PN}$ clomipramine, and $\mathrm{PN}$-citalopram but not PN-desipramine treatment significantly increased the latency to feed when compared with $\mathrm{PN}$-vehicle treatment $(p=$ $0.0003, p=0.0005$, and $p=0.0467$, respectively) (Fig. 3D). Post hoc analysis also revealed that $\mathrm{PN}$-fluoxetine and $\mathrm{PN}$ clomipramine treatment significantly increased the percentage inhibition of milk consumption in the novel situation $(p=$ 0.0056 and $p=0.0018$, respectively) whereas PN-desipramine and PNcitalopram treatment had no effect when compared with $\mathrm{PN}$ vehicle treatment (Fig. 3E).

\section{The effect of PN-antidepressant treatment on behavioral stress response}

Unlike the foregoing tests, the shock escape test assesses the behavioral response to escapable stress. In this test, an overall treatment effect was detected for the latency to escape a mild foot shock $\left(F_{(4,202)}=3.407, p=0.0101\right)$ (Fig. 4). Post hoc analysis revealed that $\mathrm{PN}$-fluoxetine, $\mathrm{PN}$-clomipramine, and $\mathrm{PN}$ citalopram treatment significantly increased the latency to escape when compared with PN-vehicle treatment $(p=0.0061, p=$ 0.0456 , and $p=0.0120$, respectively) (Fig. 4). These results demonstrate that $\mathrm{PN}$-clomipramine and $\mathrm{PN}$-citalopram treatment mimic the effect of PN-fluoxetine treatment on the behavior assessed in the shock escape test. PN-desipramine treatment did not alter behavior in this test.

\section{The effect of early versus late chronic exposure to fluoxetine} on adult emotional behavior

To investigate whether the effect of transient 5-HTT blockade on adult behavior was specific to early life exposures, we shifted the period of fluoxetine exposure and subsequent testing to a later period of development keeping the duration of exposure and the interval before testing constant. Mice at 3 months of age were treated for $18 \mathrm{~d}$ with $10 \mathrm{mg} \cdot \mathrm{kg}^{-1} \cdot \mathrm{d}^{-1}$ fluoxetine and tested behaviorally 2.5 months after cessation of treatment.

Results are shown in Table 3. No effect of treatment was detected in the open field test (total ambulatory time: $F_{(1,28)}=$ $0.150, p=0.7014$; total vertical activity: $F_{(1,27)}=0.143, p=$ 0.7078 , total ambulatory time in the periphery: $F_{(1,28)}=0.046$, $p=0.8319$; total ambulatory time in the center: $F_{(1,28)}=3.287$, $p=0.0806)$, the novelty-suppressed feeding test $\left(F_{(1,28)}=0.132\right.$, $p=0.7192)$, and the shock escape test $\left(F_{(1,28)}=0.001, p=\right.$ $0.9718)$. These data suggest that the long-term effects on emotional behavior seen with $\mathrm{PN}$-fluoxetine treatment are specific to early developmental fluoxetine exposure.

\section{Ontogeny of behavioral abnormalities in mice exposed to PN-fluoxetine}

The function of corticolimbic circuitry in human subjects is sensitive to genetic variations in the 5-htt promoter region (Heinz et 


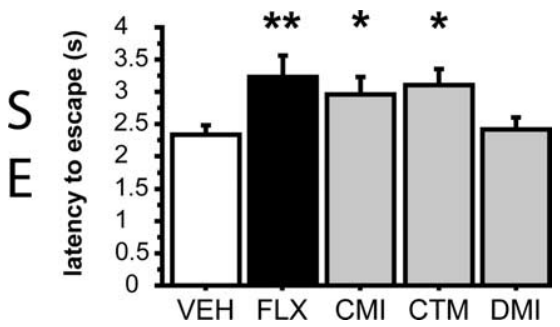

Figure 4. Behavioral stress response of $\mathrm{PN}$-antidepressant- and $\mathrm{PN}$-vehicle-treated mice. Latency to escape in the shock escape test (SE). VEH, PN-vehicle; FLX, PN-fluoxetine; CMI, PNclomipramine; CTM, PN-citalopram; DMI, PN-desipramine. Mean \pm SEM values are shown ( $n=33-55$ per group). ${ }^{*} p<0.05 ;{ }^{* *} p<0.01$ compared with PN-vehicle.

al., 2005; Pezawas et al., 2005). This reciprocal innervation of the prefrontal cortex and amygdala reaches maturity in the periadolescent period (Lewis, 1997; Blumberg et al., 2004; Davey et al., 2008). These observations have led us to hypothesize that developmental perturbations of specific circuits involved in emotional regulation might not manifest behaviorally until later in life. To test this idea, we examined behavior at several different ages after $\mathrm{PN}$-fluoxetine exposure in the open field, a paradigm that is robustly abnormal in adult PN-fluoxetine-exposed mice (Fig. $2 A, B$ ). Specifically, we tested independent and naive groups of PN-fluoxetine mice at 2, 3, and 16 months of age. Results are shown in Table 4. At 2 months of age, no treatment effect was detected for any of the measures analyzed (total ambulatory time: $F_{(1,94)}=0.119, p=0.7308$; total vertical activity: $F_{(1,94)}=0.053$, $p=0.8177$, total ambulatory time in the periphery: $F_{(1,94)}=$ $0.218, p=0.6416$; total ambulatory time in the center: $F_{(1,94)}=$ $0.310, p=0.5791)$. At 3 months of age (as previously shown), a treatment effect was detected for total ambulatory time $\left(F_{(1,104)}\right.$ $=7.574, p=0.0070)$, total vertical activity $\left(F_{(1,104)}=7.329, p=\right.$ $0.0079)$, and total ambulatory time in the periphery $\left(F_{(1,104)}=\right.$ $7.346, p=0.0079)$, but not for total ambulatory time in the center $\left(F_{(1,104)}=2.063, p=0.1540\right):$ PN-fluoxetine treatment significantly reduced novel environment exploration as measured by those measures, when compared with PN-vehicle control treatment. At 16 months of age, a treatment effect was detected for total ambulatory time $\left(F_{(1,46)}=9.115, p=0.0041\right)$, total ambulatory time in the periphery $\left(F_{(1,46)}=8.303, p=0.0060\right)$, and total ambulatory time in the center $\left(F_{(1,46)}=4.230, p=0.0454\right)$ : $\mathrm{PN}$-fluoxetine treatment significantly reduced novel environment exploration, when compared with $\mathrm{PN}$-vehicle control treatment. We also detected a trend for PN-fluoxetine treatment to reduce vertical activity when compared with $\mathrm{PN}$-vehicle treatment $\left(F_{(1,43)}=3.630, p=0.0635\right)$.

\section{Discussion}

In the present study, we confirmed several predictions regarding the temporal and neurotransmitter specificity of behavioral consequences elicited by early-life exposure to antidepressant agents. Specifically, we found that pharmacologic agents that inhibited 5-HTT function (but not NET function) during the early postnatal period altered adult behaviors related to exploration of novel environments, feeding in novel environments, and stressinduced behavior. These effects of 5-HTT inhibition were dependent on early-life exposure because shifting the treatment/testing timeframe to a later period of development did not recapitulate the effects of early exposure. Consistent with an effect on circuitry that comes "on-line" later in life, we observed that abnormal behaviors produced by postnatal 5-HTT inhibition manifested in the peri-adolescent period after which they appeared to be "permanent" under standard facility rearing conditions.

\section{Developmental pharmacologic 5-HTT blockade and adult emotional phenotypes}

$\mathrm{PN}$-fluoxetine treatment alters adult emotional behavior only in the presence of the 5-HTT (Ansorge et al., 2004). Thus, 5-HTT blockade is necessary for fluoxetine to elicit these behavioral effects. Consequently, other drugs that block 5-HTT function should also alter adult emotional behavior when given during early life. Consistent with this prediction, PN-fluoxetine and PNclomipramine treatment displayed the strongest and most robust treatment effects, PN-citalopram had intermediate effects, and PN-desipramine had no effects on emotional behaviors assessed (Table 5). Results for PN-fluoxetine/PN-vehicle comparisons mirror our previously published findings (Ansorge et al., 2004) and extend the behavioral analysis to the novelty induced hypophagia test. Results for all treatment comparisons support the notion that 5-HT, but not NE, acts during development to alter adult emotional behavior, although the ontogeny of NET expression also parallels the postnatal development of corticolimbic structures (Sanders et al., 2005).

We specifically chose 5-HTT inhibitors that differed in their structure but also their half-life in the mouse (Table 1). Our injection protocol achieved steady state drug-levels only with fluoxetine treatment. All other agents and their active metabolites were cleared from the brain within $24 \mathrm{~h}$, which allowed us to determine whether oscillating blockade of the 5-HTT during the P4-P21 period might mitigate their impact on adult behavior. We obtained evidence to support this notion. For example, PNcitalopram (the most specific 5-HTT inhibitor but also the one with the shortest half-life) produced effects in some but not all behavioral measures that were sensitive to $\mathrm{PN}$-fluoxetine treatment (Table 5). Conversely, clomipramine has an intermediate half-life in mice but primarily mimicked the effects of fluoxetine. The shorter half-life of citalopram when compared with clomipramine (Table 1) might offer an explanation for this observation.

Consistent with this study, neonatal clomipramine and citalopram treatment (from P8 to P21) alter emotional behavior in adult rats (Vogel et al., 1990; Frank and Heller, 1997; Maciag et al., 2006). The behaviors assessed in these studies (e.g., forced swim immobility, sleep behavior, and sexual behavior) differ from the behaviors assessed here, but nonetheless indicate that the effects studied in the rat could also be attributable to developmental 5-HTT blockade and suggest that the vulnerability of the 5-HT system to developmental impact is not restricted to the mouse.

\section{Developmentally sensitive window for 5-HTT inhibition}

We found that chronic, transient fluoxetine treatment in 3month-old mice had no demonstrable effects 2.5 months after cessation of treatment on the same emotional behaviors that are profoundly affected by early-life exposure to fluoxetine. These results demonstrate that the effects of $\mathrm{PN}$-fluoxetine treatment are not long-lasting withdrawal effects. Rather, they are dependent on the period of treatment and this "critical period" is at least partially contained within the P4-P21 period.

Although the 5-HTTLPR affects 5-htt expression in vitro and in lymphoblasts (Lesch et al., 1996), functional imaging studies and postmortem samples generally show no effect of 5-HTTLPR genotype on 5- $h t t$ expression in adult subjects (Mann et al., 2000; Parsey et al., 2006). This suggests that the $s$ allele acts primarily 
Table 3. Behavioral response of adult chronic fluoxetine- and vehicle-treated mice 2.5 months after cessation of treatment

\begin{tabular}{|c|c|c|c|c|}
\hline & \multicolumn{2}{|l|}{ VEH } & \multicolumn{2}{|l|}{ FLX } \\
\hline & Mean & SEM & Mean & SEM \\
\hline \multicolumn{5}{|l|}{ Open field } \\
\hline Total ambulatory time (s) & 1038.800 & 147.496 & 965.267 & 119.456 \\
\hline Ambulatory time in periphery (s) & 963.400 & 137.868 & 925.200 & 113.078 \\
\hline Ambulatory time in center (s) & 75.400 & 14.673 & 40.067 & 12.827 \\
\hline Total vertical activity (counts) & 16.857 & 5.313 & 14.333 & 4.107 \\
\hline \multicolumn{5}{|l|}{ Novelty suppressed feeding } \\
\hline Latency to feed (s) & 30.867 & 2.722 & 32.467 & 3.464 \\
\hline \multicolumn{5}{|l|}{ Shock escape } \\
\hline Latency to escape (s) & 1.759 & 0.349 & 1.775 & 0.314 \\
\hline
\end{tabular}

VEH, Vehicle; FLX, fluoxetine. $n=15$ per group

Table 4. Ontogeny of novel open field behavior in PN-fluoxetine- and PN-vehicle-treated mice

\begin{tabular}{|c|c|c|c|c|}
\hline & \multicolumn{2}{|l|}{ VEH } & \multicolumn{2}{|l|}{$\mathrm{FLX}$} \\
\hline & Mean & SEM & Mean & SEM \\
\hline \multicolumn{5}{|l|}{2 months } \\
\hline Total ambulatory time (s) & 725.197 & 37.865 & 750.257 & 69.689 \\
\hline Ambulatory time in periphery (s) & 674.820 & 674.820 & 707.600 & 65.445 \\
\hline Ambulatory time in center (s) & 50.377 & 8.198 & 42.657 & 11.450 \\
\hline Total vertical activity (counts) & 6.705 & 1.015 & 6.286 & 1.614 \\
\hline \multicolumn{5}{|l|}{3 months } \\
\hline Total ambulatory time (s) & 556.631 & 33.238 & $412.634^{* *}$ & 39.531 \\
\hline Ambulatory time in periphery $(\mathrm{s})$ & 544.062 & 32.102 & $406.000^{* *}$ & 39.026 \\
\hline Ambulatory time in center $(s)$ & 12.569 & 3.117 & 6.634 & 1.607 \\
\hline Total vertical activity (counts) & 6.908 & 1.343 & $2.268^{* *}$ & 0.326 \\
\hline \multicolumn{5}{|l|}{16 months } \\
\hline Total ambulatory time (s) & 907.409 & 121.996 & $495.385^{* *}$ & 71.609 \\
\hline Ambulatory time in periphery $(\mathrm{s})$ & 816.955 & 98.891 & $474.769^{* *}$ & 474.769 \\
\hline Ambulatory time in center $(\mathrm{s})$ & 90.455 & 35.547 & $20.615^{*}$ & 8.618 \\
\hline Total vertical activity (counts) & 3.238 & 1.152 & $1.125 \#$ & 0.250 \\
\hline
\end{tabular}

The 2-month-old group consisted of $n=35-61$ per treatment. The 3-month-old group consisted of $n=41-68$ per treatment. The 16-month-old group consisted of $n=21-26$ per treatment. VEH, PN-vehicle; FLX, PN-fluoxetine. ${ }^{*} p=0.0635 ;{ }^{*} p<0.05 ;{ }^{* *} p<0.01$ compared with PN-vehicle.

Table 5. Summary of behavioral effects seen in adult PN-antidepressant-treated mice

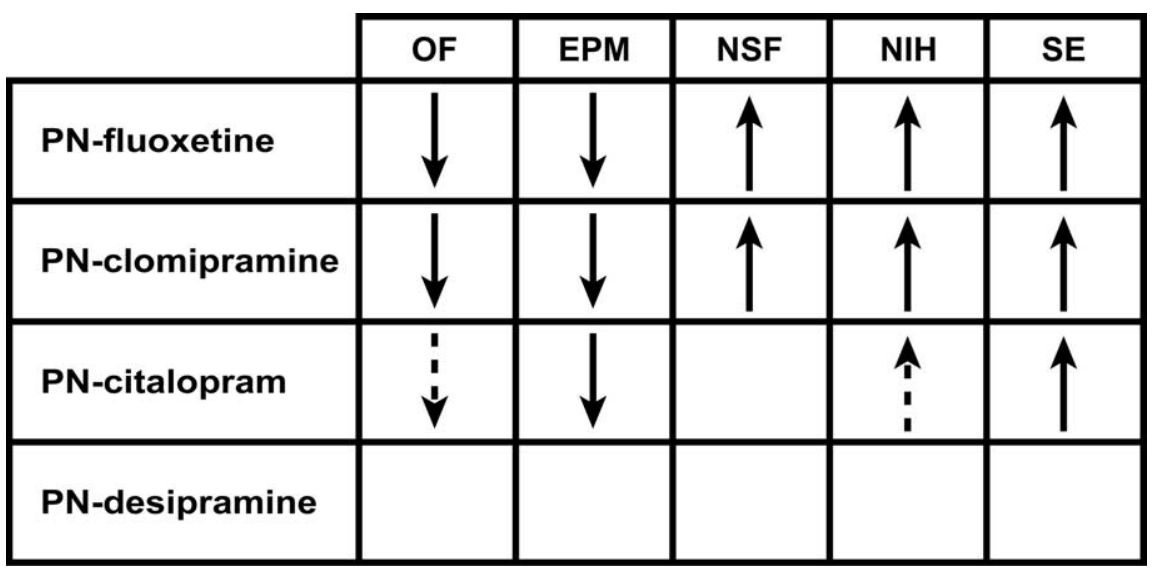

Arrows indicate statistically significant increases or decreases in the sensitive measures of the behavioral tests (drug vs vehicle): exploratory activity in the open field test (OF) and elevated plus maze (EPM), latency to feed in the NSF test, latency to feed and percentage inhibition of food consumption in the NIH test, and latency to escape in the shock escape test (SE). Solid arrows indicate that all sensitive measures in the respective test were affected; dashed arrows indicate that one of two sensitive measures was affected. Open cells indicate that drug treatment had no effect on the respective measures.

during development and less so in adult brain and would reconcile many diverse findings (including ours) that implicate altered 5-HT signaling during early development in resulting brain structure and function. Additional studies are required to test this supposition.

Brain maturation during $\mathrm{P} 4-\mathrm{P} 21$ involves a vast array of developmental processes known to be modulated by $5-\mathrm{HT}$, including neuronal differentiation, migration, growth cone elongation, axonal guidance, myelination, synaptogenesis, and dendritic pruning (Haydon et al., 1984; Lauder, 1990; Gaspar et al., 2003). We hypothesized that increased 5-HT signaling impacts these processes, ultimately affects the development of postsynaptic targeting areas, and causes alterations in adult emotional behavior. A well studied example of 5-HT impact on neural development and adult behavior is the disruption of the somatosensory barrel fields of rodents. Increased 5-HT tone during $\mathrm{P} 0-4$ disrupts the formation of barrel fields (Cases et al., 1996; Vitalis et al., 1998; Salichon et al., 2001) via an altered refinement of thalamocortical axon arbors (Rebsam et al., 2002) and subsequently leads to alterations in adult motor coordination (Salichon et al., 2001). Although perturbed barrel field formation is not likely related to the behavioral abnormalities we described (because $\mathrm{PN}$-antidepressant treatment commenced at P4), similar mechanisms affecting other brain circuits that have a different critical period of 5-HT sensitivity might be involved.

\section{Ontogeny of emotional phenotypes elicited by $\mathrm{PN}$-fluoxetine}

The 5-HTTLPR affects the connectivity of amygdala-perigenual cingulate cortex circuitry in humans (Heinz et al., 2005; Pezawas et al., 2005). Altered connectivity of this circuit in turn predicts depression ( $\mathrm{Pe}$ zawas et al., 2005). Because this circuit reaches maturity in the peri-adolescent period (Lewis, 1997; Wolterink et al., 2001; Blumberg et al., 2004; Davey et al., 2008), we hypothesized that PN-fluoxetine elicited emotional behavioral changes should manifest during peri-adolescence. Confirming this hypothesis, we found that altered behaviors in the novel open field test elicited by $\mathrm{PN}$-fluoxetine treatment were not detectable in the preadolescent period; they emerged between 2 and 3 months of age and persisted until at least 16 months of age. Our experiments do not allow us to identify the specific circuits involved. However, the late onset of behavioral changes indicates that the responsible circuitry shares the late maturation feature of the amygdala/PFC circuitry. The presence of altered behaviors in 16-month-old mice indicates that, once manifest, these altered circuits/behaviors persist throughout life when maintained in standard facility conditions.

\section{Conclusion}

Our findings demonstrate that 5-HT signaling during early life has important effects on adult behavior that are not shared by NE. The developmental period sensitive to 5 -HT perturbation ap- 
proximately corresponds to the human third trimester and lasting up to the first years of life.

Our observations suggest that human exposure to 5-HTT inhibitors during early life (e.g., pregnancy or breast-feeding) might exert similar effects to those described here for mice. However, with breast feeding, infant exposure levels are far less than those occurring during pregnancy (Suri et al., 2002; Stowe et al., 2003; Berle et al., 2004) and are therefore likely to be less significant in their impact on brain development. Ultimately, understanding the effects of perturbed 5-HT signaling on CNS circuit development may provide useful insights into the mechanism by which genetic variants predispose to affective disorders and allow a better understanding of the safety of early-life exposure to 5-HTT inhibitors.

\section{References}

Ansorge MS, Zhou M, Lira A, Hen R, Gingrich JA (2004) Early-life blockade of the 5-HT transporter alters emotional behavior in adult mice. Science 306:879-881.

Ansorge MS, Hen R, Gingrich JA (2007) Neurodevelopmental origins of depressive disorders. Curr Opin Pharmacol 7:8-17.

Argenti D, D'Mello AP (1994) The pharmacodynamics of desipramine and desmethyldesipramine in rats. J Pharmacol Exp Ther 270:512-519.

Balant-Gorgia AE, Gex-Fabry M, Balant LP (1991) Clinical pharmacokinetics of clomipramine. Clin Pharmacokinet 20:447-462.

Barr CS, Newman TK, Schwandt M, Shannon C, Dvoskin RL, Lindell SG, Taubman J, Thompson B, Champoux M, Lesch KP, Goldman D, Suomi SJ, Higley JD (2004) Sexual dichotomy of an interaction between early adversity and the serotonin transporter gene promoter variant in rhesus macaques. Proc Natl Acad Sci USA 101:12358-12363.

Berle JO, Steen VM, Aamo TO, Breilid H, Zahlsen K, Spigset O (2004) Breastfeeding during maternal antidepressant treatment with serotonin reuptake inhibitors: infant exposure, clinical symptoms, and cytochrome p450 genotypes. J Clin Psychiatry 65:1228-1234.

Berton O, Nestler EJ (2006) New approaches to antidepressant drug discovery: beyond monoamines. Nat Rev Neurosci 7:137-151.

Blumberg HP, Kaufman J, Martin A, Charney DS, Krystal JH, Peterson BS (2004) Significance of adolescent neurodevelopment for the neural circuitry of bipolar disorder. Ann NY Acad Sci 1021:376-383.

Caccia S, Cappi M, Fracasso C, Garattini S (1990) Influence of dose and route of administration on the kinetics of fluoxetine and its metabolite norfluoxetine in the rat. Psychopharmacology (Berl) 100:509-514.

Carrasco JL, Sandner C (2005) Clinical effects of pharmacological variations in selective serotonin reuptake inhibitors: an overview. Int J Clin Pract 59:1428-1434.

Cases O, Vitalis T, Seif I, De Maeyer E, Sotelo C, Gaspar P (1996) Lack of barrels in the somatosensory cortex of monoamine oxidase A-deficient mice: role of a serotonin excess during the critical period. Neuron 16:297-307.

Cooper TB, Allen D, Simpson GM (1975) A sensitive GLC method for the determination of imipramine and desmethylimipramine using a nitrogen detector. Psychopharmacol Commun 1:445-454.

Cryan JF, Markou A, Lucki I (2002) Assessing antidepressant activity in rodents: recent developments and future needs. Trends Pharmacol Sci 23:238-245.

D'Souza UM, Craig IW (2006) Functional polymorphisms in dopamine and serotonin pathway genes. Hum Mutat 27:1-13.

Davey CG, Yucel M, Allen NB (2008) The emergence of depression in adolescence: development of the prefrontal cortex and the representation of reward. Neurosci Biobehav Rev 32:1-19.

Dulawa SC, Hen R (2005) Recent advances in animal models of chronic antidepressant effects: the novelty-induced hypophagia test. Neurosci Biobehav Rev 29:771-783.

Dulawa SC, Holick KA, Gundersen B, Hen R (2004) Effects of chronic fluoxetine in animal models of anxiety and depression. Neuropsychopharmacology 29:1321-1330.

Dziedzicka-Wasylewska M, Faron-Gorecka A, Kusmider M, Drozdowska E, Rogoz Z, Siwanowicz J, Caron MG, Bonisch H (2006) Effect of antidepressant drugs in mice lacking the norepinephrine transporter. Neuropsychopharmacology 31:2424-2432.
Eschalier A, Fialip J, Varoquaux O, Makambila MC, Marty H, Bastide P (1988) Pharmacokinetic patterns of repeated administration of antidepressants in animals. I. Implications for antinociceptive action of clomipramine in mice. J Pharmacol Exp Ther 245:963-968.

Feng P, Ma Y, Vogel GW (2001) The critical window of brain development from susceptive to insusceptive. Effects of clomipramine neonatal treatment on sexual behavior. Brain Res Dev Brain Res 129:107-110.

Frank MG, Heller HC (1997) Neonatal treatments with the serotonin uptake inhibitors clomipramine and zimelidine, but not the noradrenaline uptake inhibitor desipramine, disrupt sleep patterns in adult rats. Brain Res 768:287-293.

Fredricson Overo K (1982) Kinetics of citalopram in test animals; drug exposure in safety studies. Prog Neuropsychopharmacol Biol Psychiatry 6:297-309.

Gaspar P, Cases O, Maroteaux L (2003) The developmental role of serotonin: news from mouse molecular genetics. Nat Rev Neurosci 4:1002-1012.

Gross C, Santarelli L, Brunner D, Zhuang X, Hen R (2000) Altered fear circuits in 5-HT(1A) receptor KO mice. Biol Psychiatry 48:1157-1163.

Haydon PG, McCobb DP, Kater SB (1984) Serotonin selectively inhibits growth cone motility and synaptogenesis of specific identified neurons. Science 226:561-564.

Heinz A, Braus DF, Smolka MN, Wrase J, Puls I, Hermann D, Klein S, Grusser SM, Flor H, Schumann G, Mann K, Buchel C (2005) Amygdalaprefrontal coupling depends on a genetic variation of the serotonin transporter. Nat Neurosci 8:20-21.

Heurteaux C, Lucas G, Guy N, El Yacoubi M, Thummler S, Peng XD, Noble F, Blondeau N, Widmann C, Borsotto M, Gobbi G, Vaugeois JM, Debonnel G, Lazdunski M (2006) Deletion of the background potassium channel TREK-1 results in a depression-resistant phenotype. Nat Neurosci 9:1134-1141.

Hirano K, Kimura R, Sugimoto Y, Yamada J, Uchida S, Kato Y, Hashimoto H, Yamada S (2005) Relationship between brain serotonin transporter binding, plasma concentration and behavioural effect of selective serotonin reuptake inhibitors. Br J Pharmacol 144:695-702.

Hyttel J (1994) Pharmacological characterization of selective serotonin reuptake inhibitors (SSRIs). Int Clin Psychopharmacol 9 [Suppl 1]:19-26.

Jason KM, Cooper TB, Friedman E (1981) Prenatal exposure to imipramine alters early behavioral development and beta adrenergic receptors in rats. J Pharmacol Exp Ther 217:461-466.

Kalueff AV, Fox MA, Gallagher PS, Murphy DL (2006) Hypolocomotion, anxiety and serotonin syndrome-like behavior contribute to the complex phenotype of serotonin transporter knockout mice. Genes Brain Behav 6:389-400.

Keller NR, Diedrich A, Appalsamy M, Miller LC, Caron MG, McDonald MP, Shelton RC, Blakely RD, Robertson D (2006) Norepinephrine transporter-deficient mice respond to anxiety producing and fearful environments with bradycardia and hypotension. Neuroscience 139:931-946.

Kim CH, Hahn MK, Joung Y, Anderson SL, Steele AH, Mazei-Robinson MS, Gizer I, Teicher MH, Cohen BM, Robertson D, Waldman ID, Blakely RD, Kim KS (2006) A polymorphism in the norepinephrine transporter gene alters promoter activity and is associated with attention-deficit hyperactivity disorder. Proc Natl Acad Sci USA 103:19164-19169.

Lauder JM (1990) Ontogeny of the serotonergic system in the rat: serotonin as a developmental signal. Ann NY Acad Sci 600:297-313, discussion 314.

Lesch KP, Bengel D, Heils A, Sabol SZ, Greenberg BD, Petri S, Benjamin J, Muller CR, Hamer DH, Murphy DL (1996) Association of anxietyrelated traits with a polymorphism in the serotonin transporter gene regulatory region. Science 274:1527-1531.

Lewis DA (1997) Development of the prefrontal cortex during adolescence: insights into vulnerable neural circuits in schizophrenia. Neuropsychopharmacology 16:385-398.

Lippmann M, Bress A, Nemeroff CB, Plotsky PM, Monteggia LM (2007) Long-term behavioural and molecular alterations associated with maternal separation in rats. Eur J Neurosci 25:3091-3098.

Lira A, Zhou M, Castanon N, Ansorge MS, Gordon JA, Francis JH, BradleyMoore M, Lira J, Underwood MD, Arango V, Kung HF, Hofer MA, Hen R, Gingrich JA (2003) Altered depression-related behaviors and functional changes in the dorsal raphe nucleus of serotonin transporterdeficient mice. Biol Psychiatry 54:960-971.

Maciag D, Simpson KL, Coppinger D, Lu Y, Wang Y, Lin RC, Paul IA (2006) 
Neonatal antidepressant exposure has lasting effects on behavior and serotonin circuitry. Neuropsychopharmacology 31:47-57.

Mann JJ, Huang YY, Underwood MD, Kassir SA, Oppenheim S, Kelly TM, Dwork AJ, Arango V (2000) A serotonin transporter gene promoter polymorphism (5-HTTLPR) and prefrontal cortical binding in major depression and suicide. Arch Gen Psychiatry 57:729-738.

Meaney MJ, Aitken DH, van Berkel C, Bhatnagar S, Sapolsky RM (1988) Effect of neonatal handling on age-related impairments associated with the hippocampus. Science 239:766-768.

Meng QH, Gauthier D (2005) Simultaneous analysis of citalopram and desmethylcitalopram by liquid chromatography with fluorescence detection after solid-phase extraction. Clin Biochem 38:282-285.

Murphy DL, Li Q, Engel S, Wichems C, Andrews A, Lesch KP, Uhl G (2001) Genetic perspectives on the serotonin transporter. Brain Res Bull 56:487-494.

Newman TK, Syagailo YV, Barr CS, Wendland JR, Champoux M, Graessle M, Suomi SJ, Higley JD, Lesch KP (2005) Monoamine oxidase A gene promoter variation and rearing experience influences aggressive behavior in rhesus monkeys. Biol Psychiatry 57:167-172.

Owens MJ, Nemeroff CB (1998) The serotonin transporter and depression. Depress Anxiety 8 [Suppl 1]:5-12.

Parsey RV, Hastings RS, Oquendo MA, Hu X, Goldman D, Huang YY, Simpson N, Arcement J, Huang Y, Ogden RT, Van Heertum RL, Arango V, Mann JJ (2006) Effect of a triallelic functional polymorphism of the serotonin-transporter-linked promoter region on expression of serotonin transporter in the human brain. Am J Psychiatry 163:48-51.

Pezawas L, Meyer-Lindenberg A, Drabant EM, Verchinski BA, Munoz KE, Kolachana BS, Egan MF, Mattay VS, Hariri AR, Weinberger DR (2005) 5-HTTLPR polymorphism impacts human cingulate-amygdala interactions: a genetic susceptibility mechanism for depression. Nat Neurosci 8:828-834.

Popova NK, Skrinskaya YA, Amstislavskaya TG, Vishnivetskaya GB, Seif I, de Meier E (2001) Behavioral characteristics of mice with genetic knockout of monoamine oxidase type A. Neurosci Behav Physiol 31:597-602.

Rebsam A, Seif I, Gaspar P (2002) Refinement of thalamocortical arbors and emergence of barrel domains in the primary somatosensory cortex: a study of normal and monoamine oxidase a knock-out mice. J Neurosci 22:8541-8552.

Reif A, Lesch KP (2003) Toward a molecular architecture of personality. Behav Brain Res 139:1-20.

Salichon N, Gaspar P, Upton AL, Picaud S, Hanoun N, Hamon M, De Maeyer
E, Murphy DL, Mossner R, Lesch KP, Hen R, Seif I (2001) Excessive activation of serotonin (5-HT) 1B receptors disrupts the formation of sensory maps in monoamine oxidase A and 5-HT transporter knock-out mice. J Neurosci 21:884-896.

Sanders JD, Happe HK, Bylund DB, Murrin LC (2005) Development of the norepinephrine transporter in the rat CNS. Neuroscience 130:107-117.

Stowe ZN, Hostetter AL, Owens MJ, Ritchie JC, Sternberg K, Cohen LS, Nemeroff CB (2003) The pharmacokinetics of sertraline excretion into human breast milk: determinants of infant serum concentrations. J Clin Psychiatry 64:73-80.

Suckow RF, Zhang MF, Cooper TB (1992) Sensitive and selective liquidchromatographic assay of fluoxetine and norfluoxetine in plasma with fluorescence detection after precolumn derivatization. Clin Chem $38: 1756-1761$

Suri R, Stowe ZN, Hendrick V, Hostetter A, Widawski M, Altshuler LL (2002) Estimates of nursing infant daily dose of fluoxetine through breast milk. Biol Psychiatry 52:446-451.

Tang AC, Akers KG, Reeb BC, Romeo RD, McEwen BS (2006) Programming social, cognitive, and neuroendocrine development by early exposure to novelty. Proc Natl Acad Sci USA 103:15716-15721.

Vitalis T, Cases O, Callebert J, Launay JM, Price DJ, Seif I, Gaspar P (1998) Effects of monoamine oxidase A inhibition on barrel formation in the mouse somatosensory cortex: determination of a sensitive developmental period. J Comp Neurol 393:169-184.

Vogel G, Neill D, Hagler M, Kors D (1990) A new animal model of endogenous depression: a summary of present findings. Neurosci Biobehav Rev 14:85-91.

Weigmann H, Hartter S, Bagli M, Hiemke C (2000) Steady state concentrations of clomipramine and its major metabolite desmethylclomipramine in rat brain and serum after oral administration of clomipramine. Eur Neuropsychopharmacol 10:401-405.

Wolterink G, Daenen LE, Dubbeldam S, Gerrits MA, van Rijn R, Kruse CG, Van Der Heijden JA, Van Ree JM (2001) Early amygdala damage in the rat as a model for neurodevelopmental psychopathological disorders. Eur Neuropsychopharmacol 11:51-59.

Xu F, Gainetdinov RR, Wetsel WC, Jones SR, Bohn LM, Miller GW, Wang YM, Caron MG (2000) Mice lacking the norepinephrine transporter are supersensitive to psychostimulants. Nat Neurosci 3:465-471.

Zhang X, Beaulieu JM, Gainetdinov RR, Caron MG (2006) Functional polymorphisms of the brain serotonin synthesizing enzyme tryptophan hydroxylase-2. Cell Mol Life Sci 63:6-11. 